\title{
Antimicrobial Assay of Soil Mold Isolates from Wonorejo Surabaya
}

\author{
Septia Arisanti ${ }^{1}$, Nengah Dwianita Kuswytasari ${ }^{1}$, and Maya Shovitri ${ }^{1}$
}

\begin{abstract}
This study was aimed to an examine antimicrobial activity of 34 soil molds isolates from the Wonorejo Surabaya on the growth of Gram negatif bacteria (Escherichia coli and Coliform Bacteria Group), Gram positif bacteria (Bacillus subtilis) and yeast (Saccharomyces cerevisiae). Antimicrobial ability detected with modification of dual culture antagonism assay in Potato Dextrose Agar (PDA) medium. The result showed that genus Aspergillus, Scopulariopsis, Penicillium, Paecilomyces, Fusarium, and Trichoderma were able to inhibit E. coli; while genus Aspergillus, Scopulariopsis, Penicillium, Paecilomyces, Exophiala, Stachybotrys, and Acremonium inhibit B. subtilis; further on only genus Aspergillus could inhibit group of Coliform bacteria); and genus Scopulariopsis, Penicillium, Trichoderma, and Absidia inhibited the growth of yeast $S$. cerevisiae.
\end{abstract}

Keywords-Antimivrobial assay, clearing zone, soil mold

Abstrak-Penelitian ini bertujuan untuk mengetahui kemampuan antimikroba 34 isolat kapang tanah Wonorejo Surabaya terhadap bakteri Gram negatif (Escherichia coli dan kelompok bakteri Coliform), bakteri Gram positif (Bacillus subtilis), dan yeast (Saccharomyces cerevisiae). Kemampuan antimikroba dideteksi dengan modifikasi uji antagonisme dual culture pada medium Potato Dextrose Agar (PDA). Hasil menunjukkan bahwa genus Aspergillus, Scopulariopsis, Penicillium, Paecilomyces, Fusarium, dan Trichoderma menghambat E. coli; genus Aspergillus, Scopulariopsis, Penicillium, Paecilomyces, Exophiala, Stachybotrys, dan Acremonium menghambat B. subtilis; hanya genus Aspergillus yang menghambat kelompok bakteri Coliform; dan genus Scopulariopsis, Penicillium, Trichoderma, dan Absidia menghambat yeast $S$. cerevisiae.

Kata kunci-uji antimikroba, zona bening, kapang tanah

\section{INTRODUCTION}

$\mathrm{M}$ icrobes are microscopic organisms which is comprised of bacteria, fungi and viruses. In interaction with humans, these microbes exist on the offensive. Examples of pathogenic bacteria Escherichia coli and the Coliform bacteria can cause gastrointestinal illness [1]. Molds and yeasts cause disease because it produces toxins (mycotoxins) which infect the surface of the body and attack the tissues in the body [2].

One of the efforts to fight microbes is to use other microbes that have antagonistic properties (antimicrobial) as a nuisance or other microbial metabolic inhibitors. Antagonistic microbes have the ability to produce antimicrobial antimicrobial compounds. Antimicrobial compounds produced by microbes is generally a secondary metabolite that is not used for the growth process [3], but for selfdefense and competition with other microbes to obtain nutrients, habitat, oxygen, light and others [4]. Antimicrobial compounds can be classified as an antibacterial or antifungal [5].

The microbes have the ability to produce antimicrobial and antimicrobial compounds are

Septia Arisanti, Nengah Dwianita Kuswytasari, and Maya Shovitri are with Department of Biology, FMIPA, Institut Teknologi Sepuluh Nopember (ITS), Surabaya, 60111, Indonesia. Email: septia_arisanti@yahoo.com. bacteria, aktinomycetes, and molds [6-7]. Aktinomycetes and groups of bacteria, such as the group of lactic acid bacteria and Gram-positive bacteria have been widely studied and is known as a source of various antimicrobial compounds [8]. Soil fungi that have antimicrobial activity is the genus Aspergillus, Penicillium, Paecilomyces, Trichoderma [2], and Fusarium [9] Genus-genus other soil fungi are able to produce antimicrobial compounds is not widely studied. Thus, in accordance with the opinion [2], screening isolates mold new ground, especially from various regions in Indonesia still have to be made to determine its potential as an antimicrobial agent.

In research of [10], has been isolated and purified isolates of soil fungi from Wonorejo Surabaya. Isolates has become a collection of the Laboratory of Microbiology and Biotechnology Department of Biology, ITS. Wonorejo Surabaya is one of the mangrove areas in Indonesia and included in Surabaya East Coast area with muddy substrate types [11], which is rich in organic material needed to carry out metabolism soil fungi [12]. In comparison, [2] reported that the mangrove forest areas in Jakarta were fungus genus Aspergillus, Paecilomyces, Penicillium, and Trichoderma which have antimicrobial properties against bacteria and yeast. However the potenty of soil fungi isolates Wonorejo Surabaya especially as antimicrobial was unknown, so 
this research developed to test it's antimicrobial ability.

\section{METHOD}

\section{A. Subcultures Isolates}

1. Soil fungi isolates Wonorejo Surabaya and Yeast Saccharomyces cerevisieae.

Thirty four pure isolates of soil fungi Wonorejo Surabaya region (collection of the Laboratory of Microbiology and Biotechnology Biological ITS) consisting of 17 genus of fungi, namely Aspergillus, Fusarium, Penicillium, Paecilomyces, Verticillium, Trichoderma, Scopulariopsis, Curvularia, Stachybotrys, Gliocladium, Gliomastix, acremonium, Chaetomium, Mortierella, Absidia, Exophiala and Cephaliophora inoculated into the first test tube containing solid medium Potato Dextrose Agar (PDA) slant and a Petri dish containing solid medium Potato Dextrose Agar (PDA) aseptically. Then incubated at room temperature $\left(30^{\circ} \mathrm{C}\right)$ for 3 days. Furthermore, the soil fungus culture tubes kept in a refrigerator at $4^{\circ} \mathrm{C}$ for stock cultures. Soil fungi cultured in Petri dishes as work culture, incubated returned up to 7 days.

Pure isolates of $S$. cerevisieae inoculated into 2 test tubes containing solid medium Potato Dextrose Agar (PDA) slant aseptically in duplicate and incubated at room temperature for 24 hours. Furthermore, the culture tubes used for work, while the other tube for culture preparation are also stored in the refrigerator at $4{ }^{\circ} \mathrm{C}$.

2. Isolates of Escherichia coli and Bacillus subtilis Bacteria

Bacterial isolates of $E$. coli and B. subtilis (collection of the Laboratory of Microbiology and Biotechnology Department of Biology ITS) was inoculated into 2 test tubes containing solid medium Nutrient Agar (NA) slant in duplo and aseptically, then incubated in an incubator (Memmert, BE-300 $₫$, Germany) at $37^{\circ} \mathrm{C}$ for 24 hours. Furthermore, the tube used for work, while the other tube stock cultures stored in a refrigerator at $4{ }^{\circ} \mathrm{C}$.

\section{B. Culture Test Preparation}

1. Inoculum Bacteria Escherichia coli and Bacillus subtilis

One loop aseptically cultured isolates from working 24 hours old were inoculated in $50 \mathrm{ml}$ of Nutrient Broth (NB) medium in a $100 \mathrm{ml}$ Erlenmeyer. Then incubated at room temperature $\left( \pm 30^{\circ} \mathrm{C}\right)$ with shaking at $100 \mathrm{rpm}$ on a rotary shaker (Health, HM-SR ®) for 24 hours, then performed for each bacterial dilution storied opponent in sterile distilled water. Then both starter inoculum of bacteria $E$. coli and B. subtilis cell number was calculated using the Haemacytometer Improved Neubauer to obtain the number of cells by $10^{6}$ cells $/ \mathrm{ml}$.

2. Inoculum of Coliform Bacteria Group

Aseptically $1 \mathrm{ml}$ samples of river water taken from the Kali Mas in Achievement Park Surabaya, inoculated in $9 \mathrm{ml}$ medium in duplicate as BGLBB stock culture and work culture. Then incubated in an incubator (Memmert, BE-300 $®$, Germany) at $37^{\circ} \mathrm{C}$ for 24 hours. Then for Coliform bacteria group stock cultures stored in the refrigerator at $4^{\circ} \mathrm{C}$, and for the culture of Coliform bacteria group work culture cells number calculated using a Haemacytometer Improved Neubauer to obtain the number of cells by $10^{6}$ cells $/ \mathrm{ml}$.

3. Inoculum Yeast (Saccharomyces cereviciae)

Suspension $S$. cerevisiae was prepared by inoculating one loop of pure isolates into $100 \mathrm{ml}$ YEMES broth and incubated at room temperature $( \pm$ $30^{\circ} \mathrm{C}$ ) with shaking at $100 \mathrm{rpm}$ on a rotary shaker (Health, HM-SR ()) for 24 hours [13]. The number of cells $S$. cerevisiae is calculated by enumerating the Haemacytometer Improved Neubauer to obtain the number of cells by $10^{6}$ cells $/ \mathrm{ml}$.

\section{Growth Inhibition Test}

The test is performed by the modified method of antagonism dual culture. The assay to detect secretion of antimicrobial compounds from fungi isolates and their effects on the growth of bacteria and yeast opponent.

Gram negative bacteria used E. coli and Coliform Bacteria Group, whereas Gram positive bacteria used B. subtilis, for representatives of fungi used $\mathrm{S}$. cerevisiae. Sterile cotton swab dipped in a suspension of E. coli, B. subtilis, the Coliform bacteria, and $S$. cerevisiae with each cell concentration of $10^{6}$ cells/ $\mathrm{ml}$. Then by using the swab (swab method) was inoculated on PDA solid medium in Petri dishes. Similarly one colony isolates were inoculated soil fungi Surabaya Wonorejo $1 \mathrm{~cm}$ diameter in the center of a Petri dish. Petri dishes were incubated at room temperature for 7 days. Control treatments in the form of a Petri dish inoculated with bacterial isolates only test and a Petri dish inoculated soil fungi Wonorejo Surabaya alone. Observations about the presence or absence of clear zone, clear zone diameter and the diameter of each mold colony were done every 24 hours for 7 days. The ratio between the diameter and the diameter of the mold colonies's clear zone called growth inhibition opponent microbial isolates ratio as an indicator secretion of antimicrobial compounds of soil fungi isolates from Wonorejo Surabaya.

\section{Research Design and Data Analysis}

Each soil fungi isolates from Wonorejo Surabaya tested antimicrobial against four opponent microbes, each performed three replicates and data were analyzed descriptively. The parameters were observed in the presence or absence of clear zone around soil fungi colony, diameter of mold colony, diameter of clear zone, and ratio of clear zone were counted every 24 hours for 7 days incubation period.

\section{RESULTS AND DISCUSSION}

Based on the parameters of clear zone is seen that there were 23 isolates of soil fungi from Wonorejo that are inhibiting growth of fourth microbial opponent. Figure 1 dan Table 1 shows the value of clear zone ratio. The greater ratio of clear zone, 
assumed greater the ability of the mold soil to inhibit the growth of opponent microbes.

According [14-15], clear zone is an indication of the absence or inhibition of microbial growth due to the excretion of antimicrobial compounds by other microbes opponent that are antagonistic. Clear zone around the colonies of soli mold seen since the first day or 24 hours of incubation, and then the next day covered by the growth of soil mold colonies. Soil fungi colony growth during the incubation period varies, depending on the speed of growth of each isolate soil fungi.

From 34 isolates of soil fungi were tested antimicrobial Wonorejo, there were 11 isolates were not able to inhibit the growth of microbes fourth opponent. This is not because the 11 isolates of fungi is not potentially inhibit all species of bacteria and yeast, but can be caused by microbial species opponent. According [5], each microbial species showed different susceptibility to antimicrobial compounds. So that in other bacteria and yeast species than those used in this test, the response could be different, which may be stunted due to resistance to antimicrobial compounds produced by soil fungi isolates.

Generally seen that the B. subtilis bacteria isolates greatest inhibited growth by a soil fungus Exophiala sp. (T3.8), Acremonium sp. (T3.9), A. fumigatus (T1.a6), and $A$. versicolor (T1.p3). Value ratio of the largest clear zone on each isolate soil fungi occurred on the first day of incubation. This is because the diameter of the mold colony on the first day of incubation still measuring $\pm 1 \mathrm{~cm}$. Furthermore, the diameter of the mold colony growing following the long period of incubation. While on the other hand the diameter of clear zone formed from the first day until the last day incubation period is relatively constant, thus minimizing the value of the ratio of the clear zone.

Soil mold isolates from Wonorejo inhibited the growth of both $E$. coli and $B$. subtilis bacteria. There were 11 mold isolates be antimicrobial against $E$. coli and 20 mold isolates againts B. subtilis. From Figure 1 also shows that there are only 2 mold isolates were able to inhibit the growth all of 3 opponent bacteria (E. coli, B. subtilis, and the Coliform bacteria group), which isolates $A$. niger (T2.1) and $A$. versicolor (T1.p3).

Generally, the genus Aspergillus can inhibit the growth of bacteria $E$. coli and $B$. subtilis, but not able to inhibit the yeast $S$. cerevisiae. However, for mold isolates A. niger (T2.1) and A. versicolor (T1.p3) could inhibit the Coliform bacteria. Visible clear zone around the colony mold isolates A. versicolor (T1.p3) while inhibiting the growth of bacteria $E$. coli, $B$. subtilis and the Coliform bacteria is shown in Figure 1a, b, c, while at A. versicolor (T1.p3) were tested against the yeast $S$. cerevisiae does not seem clear zone formed (Figure 2d).

There are several isolates of mold that has the greatest ability to inhibit the growth of bacteria opponents characterized by the ratio of the value of the largest clear zone between the isolates of other species. The ratio of clear zone mold isolates $A$. versicolor (T1.p3) against the $E$. coli bacteria was 2.5 $\mathrm{cm}$, mold isolates $A$. fumigatus against $B$. subtilis at $3.24 \mathrm{~cm}$, and mold isolates $A$. niger (T2.1) and $A$. versicolor (T1.p3) against Coliform bacteria in similar of $1.4 \mathrm{~cm}$.

The results are consistent with the [16-17], who reported that the mold Aspergillus isolated from soil capable of producing antimicrobial compounds that can inhibit the growth of Gram positive and negative bacteria. And [18-19] also state that A. flavus produces aflatoxin antimicrobial compounds, and $A$. niger produces malformin and $A$. fumigatus produces helvolicacid or fumigacin.

Also according [17], generally antimicrobial compounds produced by Aspergillus are neutral, polar, and has a phenol group. Phenol is capable denaturated protein on the bacterial cell wall and membrane [20]. Research on soil mold on the growth inhibition of Coliform bacteria group has not done yet and couldn't gained much information about it. According [21] Coliform bacteria as a group of rodshaped, Gram-negative, non-spore-forming, aerobic and facultative anaerobic ferment lactose and produce acid and gas within 48 hours at $35^{\circ} \mathrm{C}$. At least soil fungi isolates from Wonorejo were able to inhibit the Coliform bacteria made possible by the presence of different types of bacteria (not consisting of one species of bacteria) that live together in groups, so the secondary metabolites produced by soil mold isolates from Wonorejo difficult to inhibit the growth of those who lived with in one group.

Isolates of Scopulariopsis sp. 1 (T2.19) inhibits bacteria $B$. subtilis and the yeast $S$. cerevisiae, while Scopulariopsis sp. 2 (T3.2) inhibits bacteria E. coli and B. subtilis. None of the genus Scopulariopsis isolates were able to inhibit the Coliform bacteria. The difference in the ability to inhibit microbial opponents, might caused by differences of these two species of Scopulariopsis isolates. When compared with Aspergillus, Scopulariopsis seen slower growth. This was conclude from the no clear zone seen by the growth of mold isolates colony until the seventh day of incubation.

Scopulariopsis sp. able to inhibit the growth of Gram positive and negative bacteria [22]. This is caused by Scopulariopsis sp. able to produce antimicrobial compounds trichothecenes [23], which has a mechanism of inhibiting protein synthesis and bacterial cell DNA [24].

Three soil mold isolates Penicillium sp. 2 (T1.a2), Penicillium sp. 3 (T1.q1) and Penicillium sp. 4 (T3.f2) could inhibit the growth of bacteria $E$. coli and B. subtilis. All isolates of the genus Penicillium are not able to inhibit the Coliform bacteria, and Penicillium sp.4 (T3.f2) were able to inhibit the yeast S. cerevisiae. While Penicillium sp. 1 (T4.e3) is not able to inhibit all microbial opponents. This suggests that species differences affect the ability to inhibit a microbial opponent. 
Penicillium capable of producing the antibiotic penicillin to inhibit the synthesis of bacterial cell wall peptidoglycan [19,25]. Penicillin inhibits bacterial cell wall synthesis by inhibiting the synthesis of the enzyme or inactivation of the enzyme to synthesize peptidoglycan which an essential component of the bacterial cell wall. Inhibition of peptidoglycan synthesis causes loss of viability and often cause bacterial cell lysis. In addition, [26] states that the Penicillium sp. griseofulvin produce antimicrobial compounds that are inhibiting the growth of fungi [27], by interfering with the function of thread spindles and cytoplasmic microtubules, thus inhibiting fungal cell mitosis [28].

Five isolates of Paecilomyces seen that there are four isolates Paecilomyces sp. 1 (T2.11), Paecilomyces sp. 2 (T2.8), Paecilomyces sp. 3 (T2.20) and Paecylomyces sp. 5 (T4.6), which inhibits the growth of bacteria $B$. subtilis. Just Paecilomyces sp. 5 (T4.6) in addition to inhibiting the growth of $B$. subtilis, is also able to inhibit the growth of bacteria E. coli. All isolates of Paecilomyces sp. not able to inhibit the growth of Coliform bacteria and yeast $S$. cerevisiae. While the Paecilomyces isolates Paecilomyces sp. 4 (T3.1) are not able to inhibit all microbial opponents.

Paecilomyces reported to have antibacterial ability against E. coli [29], as well as generating Paecilospirone which inhibiting the growth of $B$. subtilis bacteria [19]. Paecilomyces can also produce antibiotic cephalosporin $\mathrm{C}$ which capable of inhibiting the growth of Gram-negative and positive [30]. Cephalosporin $\mathrm{C}$ has a mechanism of action similar to penicillin in inhibiting the growth of bacteria.

Based on the observations shows that soil mold isolates from Wonorejo the Fusarium sp. (T1.p2) is only able to inhibit the growth of $E$. coli. The ratio of the largest clear zone was seen only on the first day of incubation. Furthermore, due to rapid growth of Fusarium colonies, the clear zone can not be observed.

Fusarium that has been isolated from soil have antibacterial capabilities [22]. Fusarium produce antimicrobial compounds called trichothecenes, which has a mechanism of inhibiting protein synthesis and bacterial cell DNA [31].

Isolates Wonorejo soil fungi Trichoderma sp. 2 (T3.b1) could inhibit the growth of E. coli bacteria and the Saccharomyces cerevisiae yeast, but not for the $B$. subtilis bacteria and the Coliform bacteria. Isolates of Trichoderma sp. 1 (T2.13) does not have the ability to inhibit the growth of all microbes opponent.

Trichoderma sp. can produce Isocyanide-3-(isocyanocyclopent-2-enylidene) propionic acid and Gliotoksin [32] to inhibit the growth of E. coli bacteria. According to [33], Trichoderma sp. the enzyme 1,3-glucanase and khitinase that is antibiosis. Both enzymes are capable of destroying glucans and chitin which is a component of fungal hyphae wall.

Based on these observations, soil mold isolates from Wonorejo Exophiala sp. (T3.8) is only able to inhibit the growth of B. subtilis (see Figure 3). The ratio of the resulting clear zone of $5.52 \mathrm{~cm}$ are on the first day of incubation, and clear zone remain visible until the seventh incubation period because the growth rate of this genus are relatively slow when compared to the genus Aspergillus and Fusarium.

Exophiala sp. able to inhibit Gram-positive bacteria to produce antimicrobial compounds Chlorohydroaspyrones A and B [34], and Exophilin [35]. However, the inhibitory mechanism of action of these compounds against Gram positive bacteria is still unknown.

Soil mold Isolates from Wonorejo Stachybotrys sp. 1 (T2.7) and Stachybotrys sp. 2 (T2.10) only able to inhibit the growth of B. subtilis and other opponents of the microbes. Clear zone is only visible when the Stachybotrys sp. 1 (T2.7) were tested against $B$. subtilis. The ratio of the largest zones are on the first day of incubation. Stachybotrys genus colony growth has been rapid. This is evident from the clear zone on isolates of Stachybotrys sp. 1 (T2.7) is seen on the first day of incubation only and isolates of Stachybotrys sp. 2 (T2.10) seen from the first to the second day of incubation.

According to [36] the genus Stachybotrys potential as biological control agents against Gram-positive bacteria. Stachybotrys sp. can produce antimicrobial compounds such as trichothecenes, which has a mechanism of inhibiting protein synthesis and bacterial cell DNA [24].

Gliomastix sp. 1 (T3.6) and Gliomastix sp. (T3.7) is able to inhibit the growth of $B$. subtilis bacteria. However, all isolates Gliomastix not able to inhibit the growth of microbes other opponents. Stachybotrys genus colony growth has been rapid. Clear zone on Gliomastix sp. 2 (T3.6) isolates is seen on the first day of incubation only and isolates Gliomastix sp. 1 (T3.7) seen from the first to the second day of incubation. So the ratio of the largest zones are on the first day of incubation. And [37] reported that Gliomastix able to inhibit pathogenic bacteria by producing volatile oils. But the volatile oils and how inhibitory mechanism against Gram-positive bacteria is still unknown due to little research on that.

Acremonium sp. (T3.9) is only able to inhibit the growth of $B$. subtilis bacteria and was not able to inhibit the growth of three other microbial opponent. Acremonium colony growth is relatively slow, because the clear zone measured from the first day until the seventh day of incubation.

Acremonium producing cephalosporin $\mathrm{C}$ which has a mechanism similar to penicillin in inhibiting the growth of Gram-positive bacteria [38]. Based on the observation shows that isolates Absidia sp. (T3.k2) is only able to inhibit the growth of yeast $S$. cerevisiae. The largest clear zone on the first day of incubation. Furthermore, since the growth of Absidia colony very quickly, so clear zone can not be observed at the end of the incubation period. Absidia sp. isolated from the soil able to produce antimicrobial compounds that can inhibit the growth of yeast. However, if the compound 
has not gotten the information generated and how the mechanism in inhibiting the growth of yeast [26].

\section{CONCLUSION}

1. The soil mold isolates from Wonorejo Surabaya has antimicrobial capabilities. From 34 isolates tested, there were 11 isolates to be antimicrobial against $E$. coli (Gram-negative), 20 isolates of the B. subtilis (Gram positive bacteria), 2 isolates of the Coliform group of bacteria (Gram negative) and 4 isolates against $S$ cerevisiae (yeast). 2 The soil mold isolates that were inhibit E. coli is genus Aspergillus, Scopulariopsis, Penicillium, Paecilomyces, Fusarium, and Trichoderma with the largest value of the ratio of clear zone from the genus Aspergillus, which isolates A. versicolor (T1.p3) of $2.5 \mathrm{~cm}$.
3. The soil mold isolates that were inhibit $B$. subtilis is a genus Aspergillus, Scopulariopsis, Penicillium, Paecilomyces, Exophiala, Stachybotrys, and Acremonium with the largest value of the ratio of clear zone from the genus Exophiala sp. (T3.8) isolates of $5.52 \mathrm{~cm}$.

4. The soil mold isolates that were inhibit the Coliform Bacteria Group is derived from the genus Aspergillus isolates which were A. niger (T2.1) and $A$. versicolor (T1.p3) with the same ratio of clear zone is $1.4 \mathrm{~cm}$.

5. The soil mold isolates that were inhibit yeast $S$. cerevisiae is the genus was Scopulariopsis, Penicillium, Trichoderma and Absidia with the largest value of the ratio of clear zone from the genus Penicillium isolates of Penicillium sp. 4 (T3.f2) of $1.88 \mathrm{~cm}$

TABLE 1.

THE RATIO OF CLEARING ZONE ZONE TO COLONY DIAMETER OF SOIL MOLD ISOLATES FROM WONOREJO SURABAYA

\begin{tabular}{|c|c|c|c|c|c|c|}
\hline \multirow[t]{2}{*}{ No. } & \multirow[t]{2}{*}{ Mold isolates } & \multirow{2}{*}{$\begin{array}{l}\text { Code of } \\
\text { isolates }\end{array}$} & \multicolumn{4}{|c|}{ Clearing zone ratio $(\mathrm{cm})$} \\
\hline & & & E. coli & B. subtilis & Coliform Bacteria Group & S. cerevisiae \\
\hline 1. & Aspergillus niger & $\mathrm{T} 2.1$ & 1.84 & 2.32 & 1.4 & - \\
\hline 2. & Aspergillus versicolor & T1.p3 & 2.5 & 3.15 & 1.4 & - \\
\hline 3. & Aspergillus flavus & $\mathrm{T} 4.3$ & 2.06 & 2.5 & - & - \\
\hline 4. & Aspergillus oryzae & T1.p4 & 2.1 & 1.29 & - & - \\
\hline 5. & Aspergillus fumigatus & T1.a6 & 2,4 & 3.24 & - & - \\
\hline 6. & Scopulariopsis sp. 1 & $\mathrm{~T} 2.19$ & - & 2.76 & - & 1.6 \\
\hline 7. & Scopulariopsis sp. 2 & $\mathrm{~T} 3.2$ & 1.33 & 2.07 & - & - \\
\hline 8. & Gliocladium sp. & $\mathrm{T} 2.16$ & - & - & - & - \\
\hline 9. & Mortierella sp. & T3.g1 & - & - & - & - \\
\hline 10. & Penicillium sp. 1 & $\mathrm{~T} 4 . \mathrm{e} 3$ & - & - & - & - \\
\hline 11. & Penicillium sp. 2 & $\mathrm{~T} 1 . \mathrm{a} 2$ & 2.3 & 1.7 & - & - \\
\hline 12. & Penicillium sp. 3 & T1.q1 & 1.73 & 1.52 & - & - \\
\hline 13. & Penicillium sp. 4 & T3.f2 & - & 1.52 & - & 1.88 \\
\hline 14. & Paecilomyces sp. 1 & $\mathrm{~T} 2.11$ & - & 1.8 & - & - \\
\hline 15. & Paecilomyces sp. 2 & $\mathrm{~T} 2.8$ & - & 1.67 & - & - \\
\hline 16. & Paecilomyces sp. 3 & $\mathrm{~T} 2.20$ & - & 1.47 & - & - \\
\hline 17. & Paecilomyces sp. 4 & $\mathrm{~T} 3.1$ & - & - & - & - \\
\hline 18. & Paecilomyces sp. 5 & $\mathrm{~T} 4.6$ & 1.85 & 1.7 & - & - \\
\hline 19. & Exophiala sp. & T3.8 & - & 5.52 & - & - \\
\hline 20. & Stachybotrys sp. 1 & $\mathrm{~T} 2.7$ & - & 1.73 & - & - \\
\hline 21. & Stachybotrys sp. 2 & $\mathrm{~T} 2.10$ & - & 1.87 & - & - \\
\hline 22. & Stachybotrys sp. 3 & $\mathrm{~T} 2.12$ & - & - & - & - \\
\hline 23. & Stachybotrys sp. 4 & $\mathrm{~T} 2.14$ & - & - & - & - \\
\hline 24. & Fusarium sp. & T1.p2 & 1.86 & - & - & - \\
\hline 25. & Gliomastix sp.1 & $\mathrm{T} 3.6$ & - & 2.63 & - & - \\
\hline 26. & Gliomastix sp.2 & T3.7 & - & 1.54 & - & - \\
\hline 27. & Chaetomyum sp. & T3.f1 & - & - & - & - \\
\hline 28. & Verticillium sp. & $\mathrm{T} 3.3$ & - & - & - & - \\
\hline 29. & Acremonium sp. & T3.9 & - & 4.52 & - & - \\
\hline 30. & Trichoderma sp.1 & $\mathrm{T} 2.13$ & - & - & - & - \\
\hline 31. & Trichoderma sp.2 & T3.b1 & 1.94 & - & - & 1.63 \\
\hline 32. & Cephaliophora sp. & $\mathrm{T} 4.2$ & - & - & - & - \\
\hline 33. & Curvularia sp. & $\mathrm{T} 1.4$ & - & - & - & - \\
\hline 34. & Absidia sp. & $\mathrm{T} 3 . \mathrm{k} 2$ & - & - & - & 1.22 \\
\hline
\end{tabular}



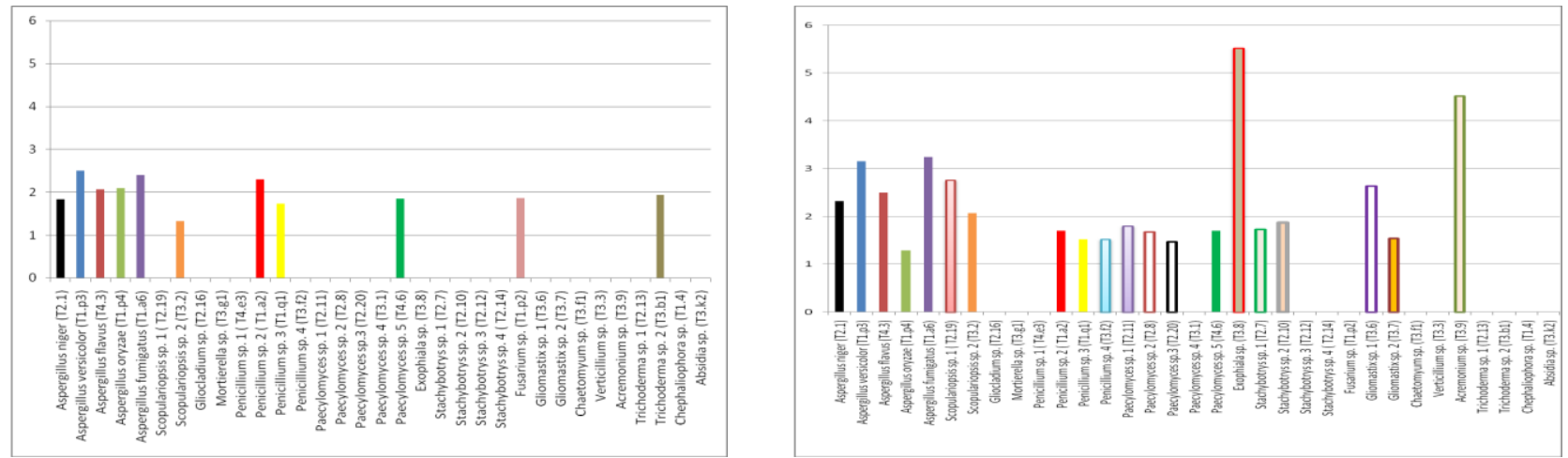

Description: - there is no clear zone, which means the soil mold isolates from Wonorejo Surabaya is not able to inhibit the growth of microbes opponent

(a)

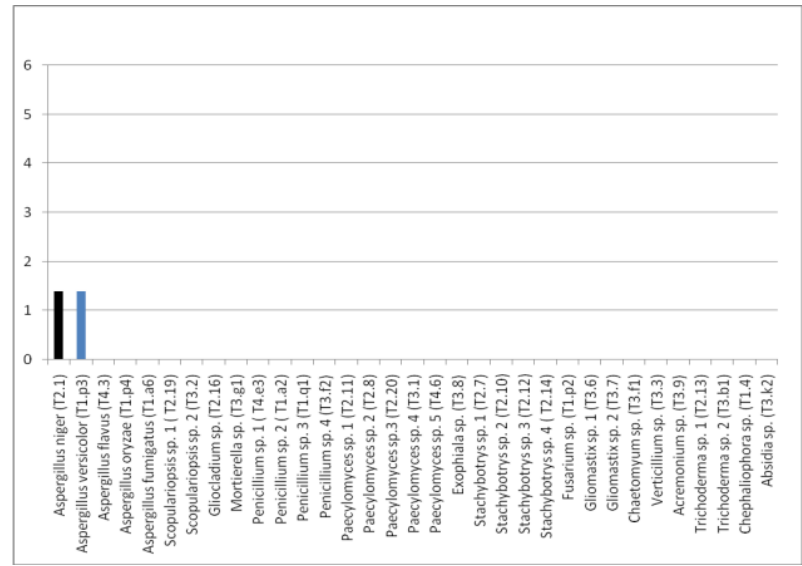

(c) (b)

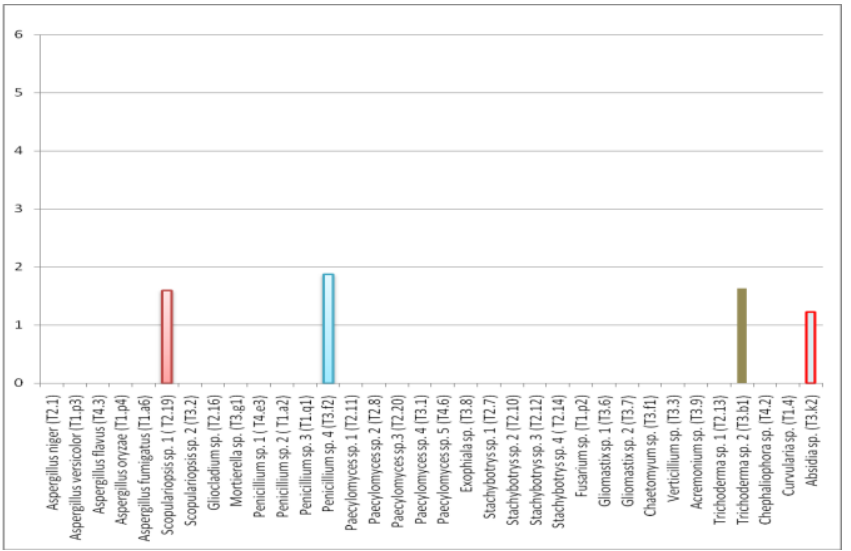

(d)

Figure 1. Graph ratio clear zone $(\mathrm{cm})$ (on the $\mathrm{x}$ axis) of soil mold isolates from Wonorejo Surabaya (on the y-axis) in inhibiting the growth of (a) E. coli bacteria, (b) B. subtilis bacteria, (c) Coliform bacteria group and (d) S. cerevisiae yeast.

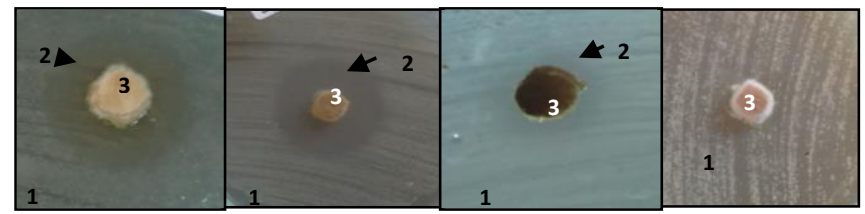

(a)

(b)

(c)

(d)

Figure 2. A. versicolor (T1.p3) against (a.) E. coli, (b.) B. subtilis, (c.) Coliform bacteria group, (d.) S. cerevisiae yeast on the first day of incubation with the description: 1. Microbial opponent, 2. clear zone, 3. isolates fungus A. versicolor.

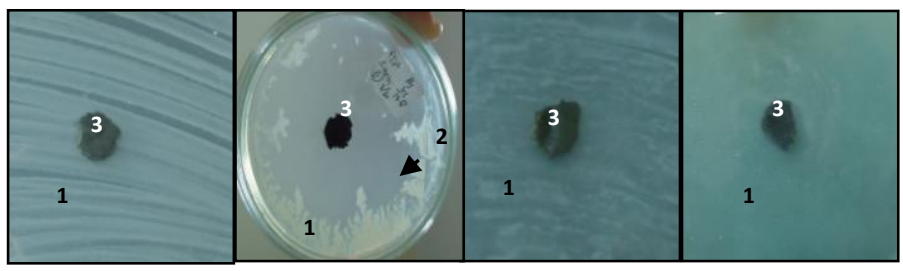

Figure 3. Exophiala sp. (T3.8) against (a a.) E. coli, (b.) B. subtilis, (c.) Coliform bacteria group, (d.) S. cerevisiae yeast on the first day of incubation with the description: 1. Microbial opponent, 2. clear zone, 3. isolates fungus Exophiala sp. 


\section{REFERENCES}

[1] L. Waluyo, Mikrobiologi Lingkungan. UMM Press, Malang, 2009, pp. 1-9.

[2] I. Gandjar, W. Sjamsuridzal, and A. Oetari, Mikologi Dasar dan Terapan. Yayasan Obor Indonesia, Jakarta, 2006, pp. 10-16, 57-65, 69, 72, 92, 108-110, 119, 139140.

[3] G. H. Schlegel, General Microbiology. Cambridge University Press: England, 1993.

[4] Baker and Crok, The Nature dan Practice of Biological Control of Plant Pathogens. $3^{\text {rd }}$ Edition: The American Phytopathological Society, 1974

[5] Pelczar and Chan, Dasar-Dasar Mikrobiologi. UI-Press, Jakarta, 2005. pp. 100-101, 107-108, 139-142, 193-196, 219.

[6] M. Radji, "Peranan Bioteknologi Dan Mikroba Endofit Dalam Pengembangan Obat Herbal". Majalah Ilmu Kefarmasian. vol. 2, no. 3, pp. 113 - 126, 2005.

[7] G. J. Tortora, B.R. Funke, dan C.L. Case. Microbiology an Introduction $8^{\text {th }}$ ed. Pearson, New York, 2002, pp. 559-560.

[8] D. G. Hoover and H. Chen, "Bacteriocin Dan Their Food Applications". Compherensive Reviews Food Science dan Food Safety. vol. 2, pp. 82-100, 2003.

[9] P. Nemec, Z. Barath, and V. Betina, dan M. Kutkova, Antibiotic Activity of Fungi Isolated From Soil Samples From Indonesia. Slovak Academy of Science: Bratislava, 1963

[10] N. D. Kuswytasari, M. Shovitri, dan R. D. Andriyadi, Soil Mold Diversity in the Coastal Wonorejo, Surabaya, in Proceeding International Conference on Mathematics and Science (ICOMSc) Mathematic and Science for Improving Human Welfare, 2011.

[11] F. Hawatofat, "Struktur Komunitas Mangrove Di Daerah Wonorejo Pantai Timur Surabaya". Abstrak Skripsi. Universitas Airlangga . Surabaya, 2006.

[12] S. Rao, Mikroorganisme Tanah dan Pertumbuhan Tanaman. Edisi Kedua. UI Press: Jakarta, 1994.

[13] S. Petersson and J. Schnurer, "Biocontrol of Mold Growth in Hight-Moisture Wheat Stored under Airtight Condition by Pichia anomala, Pichia guilliermondii, dan Saccharomyces cerevisiae". Swedish University of Agricultural Science. Applied dan Eviromental Microbiology, vol. 61, no. 3, pp. 1027-1032, 1995.

[14] S. Kumala, E. Agustina, dan P. Wahyu, "Uji Aktivitas Antimikroba Metabolit Sekunder Kapang Endofit Tanaman Trengguli (Cassia futula $\mathrm{L}$ ) (Antimicrobialaciivi Tets Of Secondary Metabolite of Endophytic Fungi From Cassia futula L )". Jurnal Bahan Alam Indonesia. vol. 6, no. 2, pp. 46-48, 2008

[15] S. Chareprasert, J. Piapukiew, S. Thienhirun, A. J. S. Whalley, and P. Sihanonth, "Endophytic fungi of teak leaves Tectona grdanis L. dan rain tree leaves Samanea saman Merr.", Research Centre for Bioorganic Chemistry. Department of Microbiology, Faculty of Science, Chulalongkorn University, Bangkok, 2005.

[16] N. Kasanah, Amini and Wahyono. Karakterisasi Senyawa Antimikroba Isolat Aspergillus sp. Hasil Isolasi dari Tanah. Majalah Farmasi. vol. 9, no. 4, pp. 166-173, 1998.

[17] P. Jain and R.K. Pundir, "Effect Of Fermentation Medium, $\mathrm{pH}$ and Temperature Variations On Antibacterial Soil Fungal Metabolite Production". Journal of Agricultural Technology.vol. 7, no. 2, pp. 247269,2010

[18] Y. S. N. Praveena and P. Padmini, "Antibacterial Activities of Mycotoxins from Newly Isolated Filamentous Fungi”. International Journal of Plant, Animal, and Enviromental Science. vol. 1, no. 1, pp. 8-13, 2011.

[19] R. J. Cole, and M. A. Schweikert, Handbook of Secondary Fungal Metabolites. Academic Press Elsevier Science, California, 2003, pp. 91, 778, 941

[20] I. P. Singh and S. B. Bharate, "Anti-HIV Natural Products”. Journal Current Science. vol. 89, no. 2, pp. 269-290, 2005.
[21] I. Supardi, Mikrobiologi dalam Pengolahan dan Keamanan Pangan. Alumni, Jakarta, 1999, p. 184.

[22] G. C. Kumar, P. Mongolla, J. Joseph, Y. V. D. Nageswar, dan A. Kamal, "Antimicrobial Activity From the Extracts of Fungal Isolates Of Soil dan Dung Samples from Kaziranga National Park, Assam, India". Journal de Mycologie Médicale, , 2010, vol. 20, pp. 283-289.

[23] K. F. Nielsen, M. O. Hansen, T. O. Larsen, dan U. Thrane, "Production Of Trichothecene Mycotoxins On Water Damaged Gypsum Boards In Danish Buildings". International Biodeterioration dan Biodegradation. Vol. 42, no. 1, pp.1-7, 1999

[24] A. Lugauskas, Potential Toxin Producing Micromycetes On Food Raw Material and Products of Plant Origin. Botanica Lithuanica.Suppl, vol. 7, pp. 3-16, 2005.

[25] J. W. Deacon, Fungal Biology. Blackwell Publishing, Malden, 2006, pp.123.

[26] M. D. Makut and O. A. Owolewa, Antibiotic-Producing Fungi Present In The Soil Environment Of Keffi Metropolis, Nasarawa State, Nigeria. Trakia Journal of Sciences. vol. 9, no. 2, pp. 33-39, 2011.

[27] J. M. Wright, "The Production of Antibiotics In Soil: II. Production of Griseofulvin by Penicillium nigricans". Annuals of Applied Biology. vol. 43, no. 2, pp.: 288-296, 1955

[28] D. Panda, K. Rathinasamy, M. Santra, and L. Wilson, "Kinetic suppression of microtubule dynamic instability by griseofulvin: Implications for its possible use in the treatment of cancer". PNAS. vol. 102, no. 28 , pp. 98789883,2005

[29] L. Lillo, A. Julio, L. C. Carlos, C. Gerardo, C. Patroisia, and C. Claudia, "Antibacterial Activity of an Oligosaccharide of Native Paecilomyces sp. dan Its Aminoglycosylated Derivative”. Z. Naturforsch. vol. 66, pp. $123-128,2011$

[30] M. A. Pisano and E. M. Vellozzi, "Production of Cephalosporin C by Paecilomyces persicinus P-10". Antimicrobial Agents and Chemotherapy. vol. 6, no. 4, pp. 447-451, 1974.

[31] S. A. Waksman, A. H. Romano, H. Lechevallier, N. J. Frederic, and M. D. Raubitschek, "Antifungal Antibiotics". Journal Series Paper. vol. 6, pp. 163-172, 1952

[32] M. Verma, S. K. Brar, R. D. Tyagi, R. Y. Surampalli, J. R. Valero, "Antagonistic Fungi, Trichoderma spp.: Panoply of Biological Control". Biochemical Engineering Journal. vol. 3, no.7, pp. 1-20, 2007.

[33] D. Zhang, X. Yang, J. S.Kang, H. D. Choi, dan W.H. Son, "Chlorohydroaspyrones A dan B, Antibacterial Aspyrone Derivatives from the Marine-Derived Fungus Exophiala sp". Journal of Natural Product, vol. 71, no.8, pp.1458-1460, 2008.

[34] J. Doshida, H. Hasegawa, H. Onuki, and N. Shimidzu, "Exophilin A, a new antibiotic from a marine microorganism Exophiala pisciphila. Jounal Antibiotic". vol. 49, no. 11, pp.1105-1109, 1996

[35] T G.aylor, X. Wang and S. H. Jabaji-Hare, "Detection of the mycoparasite Stachybotrys elegans, using primers with sequence-characterized amplification regions in conventional dan real-time PCR". The Canadian Journal of Plant Pathology-Revue Canadienne de Phytopathologie, vol. 25, no. 1, pp. 49-61, 2002.

[36] J. Zhao, T. Shan, Y. Huang, X. Liu, G. Xiwu, W Mingan, J. Weibo, and $Z$. Ligang. "Chemical composition dan in vitro antimicrobial activity of the volatile oils from Gliomastix murorum dan Pichia guilliermondii, two endophytic fungi in Paris polyphylla var. yunnanensis". Nat Prod Commun. vol. 4, no. 11, pp. 1491-1496, 2009

[37] C. Tollnick, G. Seidel, M. Beyer, and K.Schügerl, "Investigations of the Production of Cephalosporin $\mathrm{C}$ by Acremonium chrysogenum ", Journal Biotechnology, vol. 86 , pp. $1-45,2004$ 